\title{
Residents' perceptions of tourism impact and their support for tourism development: the case study of Cuc Phuong National Park, Ninh Binh province, Vietnam
}

\author{
Pham Hong Long ${ }^{1 *}$ and Kalsom Kayat ${ }^{2}$
}

Received: 19/11/2010 Accepted: 11/02/2011

\begin{abstract}
${ }^{1}$ Faculty of Tourism Studies, College of Social Sciences and Humanities, Vietnam National University, Hanoi, Vietnam; PhD Candidate, Graduate School of Tourism, Rikkyo University, Saitama, Japan; 1-2-26 Kitano, Niiza-shi, Saitama 352-8558 Japan; tel: +81-90-6044-1076; email: phamhonglong@gmail.com longph@vnu.edu.vn;

${ }^{2}$ Associate Professor, Tourism and Hospitality Programme, UUM College of Art and Sciences, Universiti Utara Malaysia, 06010 UUM Sintok, Kedah, Malaysia

* Corresponding author
\end{abstract}

\begin{abstract}
Cuc Phuong National Park (CPNP) is Vietnam's first national park, which has become a model for national parks and protected systems in Vietnam since its establishment in 1962. In spite of its importance to tourism, no systematic analysis has been undertaken thus far to understand the perceptions of its residents toward tourism in their area. Guided by the Social Exchange Theory, this study investigated Cuc Phuong National Park (CPNP) residents' perceptions of tourism impacts and their support for tourism development in their areas. Additionally, the study also explored how demographic factors (age, gender, ethnicity, place of birth, marital status and level of education, household monthly income, job status and length of residency) explain residents' perceptions and their support. It was found that residents in general have positive perceptions towards the impacts brought by tourism in CPNP especially with regards to its social-cultural and environmental impacts and they strongly supported tourism development. However, these perceptions differ according to residents' socio-demographic characteristics. The study also revealed that residents' age and gender and their perceptions of tourism impacts could be predictors for their support for tourism development in CPNP. Based on these findings, the concluding part discusses the study's implications and provides suggestions for the future.
\end{abstract}

(C) 2011 International University College. All rights reserved

Keywords: Residents' perception, tourism impacts, social exchange theory, Cuc Phuong National Park, Vietnam

Citation: Long, P.H., K. Kayat (2011) Residents' perceptions of tourism impact and their support for tourism development: the case study of Cuc Phuong National Park, Ninh Binh province, Vietnam. European Journal of Tourism Research 4(2), pp. 123-146

\section{Introduction}

In recent decades, tourism has become an important component of economic development programs around the world, especially in rural communities in developing countries where tourism often assume the important role of alleviating poverty and boosting local economies. However, the developmental 
benefits gained from tourism may not always be possible, if the negative impacts on communities outweigh any economic, sociocultural, and environmental benefits.

Tourism impact is a popular research topic in tourism whereby many researchers have studied residents' attitudes toward and perceptions of the impacts of tourism development, with the justification that the findings would be critical in tourism planning and management (see for example, Allen et al.1993 Dyer et al. 2007; Fredline \& Faulkner, 2000 and Ko \& Stewart, 2002). Other reasons for interest in this topic are based on the increasing cases of evidence on how tourism can generate both positive and negative outcomes (Lankford \& Howard, 1994), and that residents' support is essential for sustainable tourism growth (Chen, 2001; Ramchander, 2004). Tourism industry relies heavily upon the local residents' goodwill, participation and support, and therefore it should be developed according to the local residents' need and desires. Since the positive attitude of residents is essential for visitor satisfaction and repeat visitation, determining local residents' perception of tourism development and its impacts is critical in the future success of a destination (Andriotis, 2005; Yoon et al., 2001). Effective tourism planning requires understanding of these impacts from the residents' perspectives.

The main aim of this study is therefore to shed some light on how residents surrounding Cuc Phuong National Park (CPNP) perceive tourism impacts and its development. The awareness of residents' attitudes, perceptions and expectations from tourism impacts and its development are "paramount" (Chen, 2001) in order to identify real concerns and issues for appropriate policies and actions to take place, and eventually to gain support from the tourism industry. Residents draw their conclusions and their support based on the relative weightings they attach to the benefits and the costs that they perceive to have been brought by tourism to themselves and to their community (Andriotis \& Vaughan, 2003). If the residents of a host community perceive that the total impacts are negative, the level of support from the host community is likely to be weak which in turn will 124 not be beneficial for the development of the destination in the long run. Thus, another aim of this study is to assess the relationships between CPNP residents' perceptions of tourism impacts, their evaluation of these impacts and their support for tourism development. In addition, the study also seeks to understand the factors, specifically the sociodemographic factors, which may explain these perceptions and support levels. The specific research questions that have guided the study are as follows:

1. What are the socio-demographic characteristics of residents in CPNP?

2. How do CPNP residents perceive tourism impacts and how do they evaluate these impacts? How do they support tourism development in CPNP?

3. Do the CPNP residents with different sociodemographic characteristics differ in their perceptions and evaluation of tourism impacts, and their support for tourism development?

4. Which of the variables under study explain the residents' support for tourism development in CPNP?

\section{Literature review}

The range of impacts from tourism is broad and often influences areas beyond those commonly associated with tourism (Kreag, 2001). Exact types and magnitudes of impacts are almost impossible to measure, as they cannot possibly be regarded separately as it is not easy to distinguish between the effects brought by tourism alone and the effects generated by other agents of change, such as modernization, development, and the influence of media (Archer \& Cooper, 1994; Lickorish \& Jenkin, 1997; Mathieson \& Wall, 1982). The extent to which tourism has contributed to economic, social or environment problems of an area, as well as problems within the area. which have already existed prior to the existence of tourism is not often known precisely (Mathieson \& Wall, 1982). Finally, the fact that different destinations experience different impacts or even the same impacts but with different degrees/stage, adds to the difficulty in comprehending impacts brought by tourism.

In addition, the challenge in assessing tourism impacts exists due to different views held by 
different authors and authorities in the field. This is probably what is meant by Mathieson and Wall (1982) when they claim that "there is little consensus as to what should be included" (Mathieson \& Wall, 1982: 3) as impacts from tourism development, which then leads to contradictions and ambiguities in findings of research in this area. For instance, some authors in their economic impact of tourism studies just concentrate on the balance of payments, whereas others are devoted to the generation of income or the creation of employment.

There are a number of ways to categorize the impacts of tourism. Kreag (2001) in his research, divided tourism impacts into seven general categories in the form of economic, environmental, social and cultural, crowding and congestion, services, taxes, and community attitude. Archer and Cooper (1994), separated tourism impacts into economic, political, socio-cultural, environmental and ecological effects. Much earlier, Inskeep (1991), in his prevalent book "Tourism Planning - An Integrated and Sustainable Development Approach" divided tourism impacts into just two categories namely, socioeconomic impacts and environmental impacts. However, tourism impacts are most commonly grouped into three categories, which are economic impacts, physical or environment impacts, and social impacts (Ap \& Crompton, 1998; Mathieson \& Wall, 1982). As the present authors feel that social impacts most often include cultural impacts, this study follows the "traditional categories" (Ap \& Crompton, 1998) and categorizes tourism impacts as economic, physical or environmental and social-cultural impacts.

Findings from previous studies indicate that socio-demographic characteristics such as age, gender, ethnicity, education, income, job status, etc. might or might not significantly influence residents' attitudes, perceptions and evaluation of tourism impacts and tourism development. However, ambiguities in these findings exist. While some studies found sociodemographic characteristics of residents to significantly explain differences in residents' attitudes, perceptions and evaluation of tourism impacts (Andriotis, 2004; Chen, 2000, 2001; Haralambopoulos \& Pizam, 1996; Kuvan \& Akan, 2005; Nunkoo \& Ramkissoon, 2010; Ritchie \& Inkari, 2006; Williams and Lawson, 2001), contrary findings were produced by other studies (Allen et al., 1993; Brayley \& Var, 1989, Harvey, Hunt \& Harris, 1995; Johnson, Snepenger \& Akis, 1994; King, Pizam \& Milman, 1993; McCool \& Martin, 1994; Milman \& Pizam, 1988; Perdue, Long \& Allen, 1990; Ryan \& Montgomery, 1994; Ryan, Scotland \& Montgomery, 1998; Tosun, 2002). This create a vagueness, which can be attributed to the fact that different tourism destinations having different population characteristics and that tourism impacts are formed by site specific conditions under which tourists and hosts interact (Kuvan \& Akan, 2005; Tosun, 2002). This study attempts to test the association between residents' socio-demographic characteristics (age, gender, ethnic, place of birth, marital status, level of education, household monthly income, job status, length of residency) and residents' perceptions of tourism impacts, their evaluation of tourism impacts, and their support for tourism development.

Several models and theoretical perspectives have been developed or utilized to help explain residents' perceptions of and attitudes toward tourism development and its impacts. Among these models are the equity theory, growth machine theory, power theory, stakeholder theory, identity theory (see for more detail in Easterling, 2004; Harill, 2004; Kayat, 2000 and Nunkoo, Gursoy \&Juwaheer, 2010), social exchange theory, Doxey's Irridex Model (see for more detail in Harrill, 2004), Butler's (1980) Tourist Area Life Cycle Model, and community attachment model.

The Tourism Cycle Development Framework models by Doxey and Butler offer a reflection of residents' perceptions of tourism. The framework explains that resident attitudes towards tourism change as the tourism industry develops (Hernandez et al. 1996) and suggests that communities have a certain capacity to absorb tourists. Although this framework provides useful assessment criteria for exploring the community's attitudes at certain 
stages of tourism development, the models are restricted as they do not take into account the fact that different individual residents react differently to tourism development. Besides the fact that residents' perceptions can be influenced by the complexity of factors, these models overlook the fact that residents are not homogeneous in terms of their attitudes towards tourism (Kayat, 2000). Moreover, these models have only one direction in community reactions, which is rather unrealistic (Kayat, 2000).

Community attachment, on the other hand, can be another important variable that influence residents' perceptions towards tourism, tourism impacts and support for tourism development. Generally, community attachment is dependent upon length of residence. Community attachment and residents' attitudes towards tourism development suggest that highly attached residents tend to view tourism development more favourable. In this study, community attachment is assessed through length of residency.

Thomason et al. (1979) and Lankford and Howard (1994) began their studies with the guidance of the Tourism Cycle Development Model and came up with similar findings: resident attitudes are influenced by what they value. Wang and Pfister (2008) shared the same findings in their studies when indicating that residents' attitudes toward tourism are not simply the reflections of residents' knowledge about tourism impacts but also influenced by residents' values and personality. It can be concluded then, that how residents assess the costs and benefits of tourism plays a role in determining their attitude - a suggestion offered by social exchange theory, which is discussed next. Since then, many studies have confirmed that residents' attitudes toward and perceptions of tourism and tourism impacts can be explained using social exchange theory(Andereck, et al.2005; Andriotis, 2005; Andriotis \& Vaughan, 2003;Ap, 1990, 1992; Chen, 2000, 2001; Getz, 1994; Gursoy, Jurowski \& Uysal, 2002;Jurowski, et al., 1997; Kayat, 2000, 2001, 2002; Lindberg \& Johnson, 1997; McGehee, Andereck \& Vogt, 2002; McGehee \& Andereck, 2004;Nunkoo, Gursoy \& Juwaheer, 2010; Nunkoo \& Ramkissoon, 2010; 126
Sirakaya, Teye \& Sönmez, 2001, 2002; Wang \& Pfister, 2008; Yoon et al.,2001;). Social exchange theory is "a general sociological theory concerned with understanding the exchange of resources between individuals and groups in an interaction situation" (Ap, 1992: 668 ), which suggests that people evaluate an exchange based on the costs and benefits incurred as a result of that exchange. Voluntary actions of individuals are motivated by the returns they expect to receive from others. With these returns acting as goals, an individual or a party engages into an exchange with others. In other words, an individual who perceives benefits resulting from an exchange is likely to evaluate it positively, while one who perceives costs is likely to evaluate it negatively. Thus, residents who find that the exchange benefits them and increase their well-being are more likely to have positive reactions to tourism and therefore support tourism development. Residents who find the exchange problematic, correspondingly, will oppose tourism development. Jurowski et al. (1997) applied the social exchange theory to examine community support for tourism in five counties surrounding the Mt. Rogers National Recreation Area located in southwest Virginia and found that resident perception of tourism impact is a result of assessing benefits and costs, and that this evaluation clearly depends on what the resident value. For example, the study found that respondents with strong eco centric attitudes did not perceive tourism favourably as they put high value on the environment and feel that tourism have the potential to harm the environment. In addition to value held by residents, Kayat (2000) also found that residents' evaluations of tourism impacts is influenced by their ability and willingness to adapt to the changes brought by tourism in their community. Cordero (2008) suggested that if the social exchange theory is to gain academic and practical acceptance, the theory need to be further tested due to the complex nature of the interrelationship proposed in the model and to the complexity of residents as both isolated and collective individuals.

For the purpose of this study, social exchange theory is used to guide the investigation on residents' perceptions of tourism impacts and their support for tourism development in the 
case of CPNP, Ninh Binh, Vietnam. The reason is due to the fact that residents' perceptions of the impacts of tourism development are partially based on the socio-cultural, economic and environmental trade-offs and they, in turn, may influence to residents' support for tourism development. Furthermore, social exchange theory is a logically and intuitively appealing theory to formulate the basic of an investigation of the residents' perceptions of tourism impact and their support for tourism development in the case of CPNP.

\section{Problem statement}

Earlier researchers and scholars have suggested that numerous research examining tourism impacts and residents' attitudes have been conducted in developed and industrialized economies, with only a few studies carried out in developing countries (Nepal, 2008; Nunkoo, Gursoy \& Juwaheer, 2010 and Teye, Sönmez \& Sirakaya, 2002). In addition, and that despite the availability of some research on residents' attitudes toward tourism and it impacts, it is necessary to conduct additional research on this topic in other geographical locations, in different settings, and over a period of time. This will not only reinforce earlier findings but also identify and explore other factors that may influence the host residents' perceptions of and attitudes toward tourism, its impacts, and their support for tourism development; such studies will further the development of theory in this field (Andriotis, 2004, 2005; Cavus \& Tanrisevdi, 2003; Haralambopoulos \& Pizam,1996; Kuvan \& Akan, 2005; Sheldon \& Var, 1984; Smith \& Krannich, 1998; Yoon et al., 2001).

Since the early 1990s, tourism has received considerable attention in the economic development strategy of Vietnam. It is seen as an important component to diversify rural economic opportunities (UNDP, 1997). Local communities associated with tourism destinations are looking increasingly to tourism to provide economic opportunities and funds (Sheed, 2003). In fact, communities living in and around tourism destinations may thus be affected by tourism impacts, either positively or negatively. The recent years have seen growth in community-based tourism in Vietnam. Unfortunately, research on its development, planning, and impacts have not been given much attention.

The site selected in this study is Cuc Phuong National Park (CPNP), in Ninh Binh province, Vietnam. This particular site was chosen for the case study because it is a well-established and well-known tourist site in Vietnam. CPNP was established in 1962 as Vietnam's first national park. Ever since its foundation, Cuc Phuong has been the model for other national parks and protected systems in Vietnam. In spite of the importance of tourism to Cuc Phuong and the knowledge that the attitudes and perceptions of local residents are vital for the success of tourism, little is known about the local residents' perceptions of tourism. Numerous research have been undertaken to study tourism activities in CPNP. However, no published research has, so far, dealt with the residents' perception of the impacts of tourism and their attitudes toward and support for tourism development in Cuc Phuong. Hence, there is a need for a study that will build on the existing, albeit limited body of knowledge concerning the local residents' perceptions of tourism impacts and their attitudes toward and support for tourism development. A systematic analysis of these aspects among the CPNP residents can help local authorities, planners, community decision-makers, tour-operators, and tourism promoters to identify real concerns and issues in order to implement appropriate and effective policies and actions in the area, thus optimizing the benefits and minimizing the problems associated with tourism.

\section{The conceptual framework and the research hypotheses \\ Conceptual framework}

Based on the literature review, a conceptual framework for the study is depicted in Figure 1. According to the framework, residents' perceptions of tourism impacts as well as their overall evaluation of tourism impacts and their support for tourism development are determined by their socio-demographic characteristics. Residents' socio-demographic characteristics, their perceptions of tourism impacts and overall evaluation of tourism impacts determine their support for tourism development. 


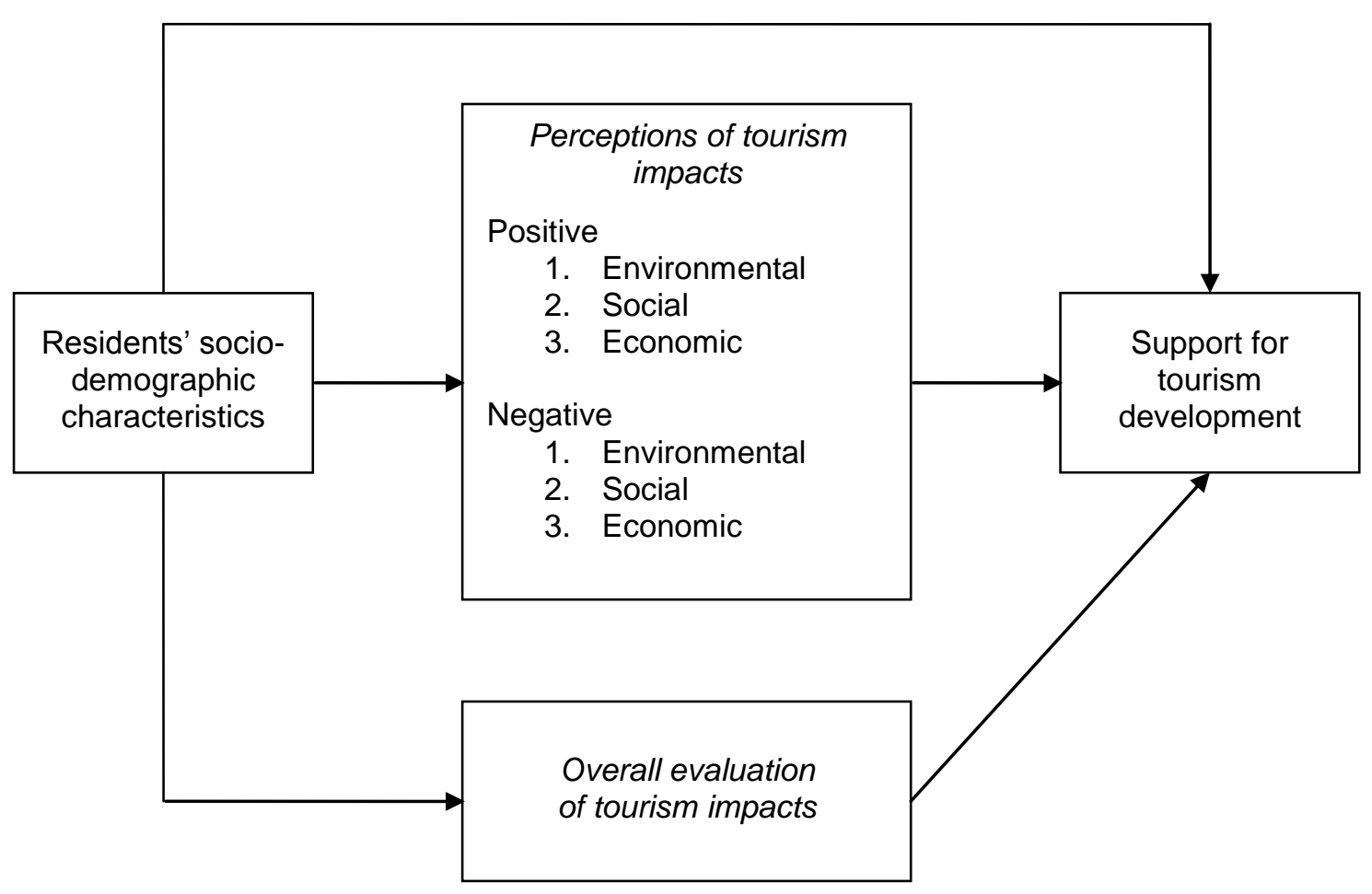

Figure 1. A framework on residents' perceptions and support levels

It is proposed that the social exchange theory is useful in explaining residents perceptions towards tourism impacts and support for tourism development, this theory proclaims that if residents perceive that the positive impacts of tourism development will be greater than negative impacts, they are inclined to be involved in the exchange and, therefore, support tourism development in their community (Yoon et al., 2001).

\section{Research hypotheses}

The hypotheses developed for this study are:

Hypothesis 1: There are no differences among residents' socio-demographic characteristics with respect to perceptions of tourism impacts, overall evaluation of impacts, and their support for tourism development.

Hypothesis 2: The independent variables (residents' socio-demographic characteristics, residents' perceptions of tourism impacts, residents' evaluation of tourism impacts) do not significantly explain the dependent variable (residents' support for tourism development).

\section{Research methods}

Survey instrument

A survey questionnaire method was used for data collection. The questionnaire consisted of 53 items which are divided into 4 parts as follows:

1. Parts 1-3: Forty-three statement items meant to measure residents' perceptions of tourism impacts, their overall assessment of tourism impacts, and their support for tourism development in CPNP were included in these parts, followed by a five-point Likert scale for the respondents' opinions $(1=$ strongly disagree, $2=$ disagree, $3=$ undecided $/$ neutral, $4=$ agree, $5=$ strongly agree).

2. Part 4: This part comprised of nine questions pertaining to the socio-demographic characteristics of residents. The last question in Part 4 requested the respondents to provide any additional comments that they wished to make regarding tourism development in their community and in CPNP. 


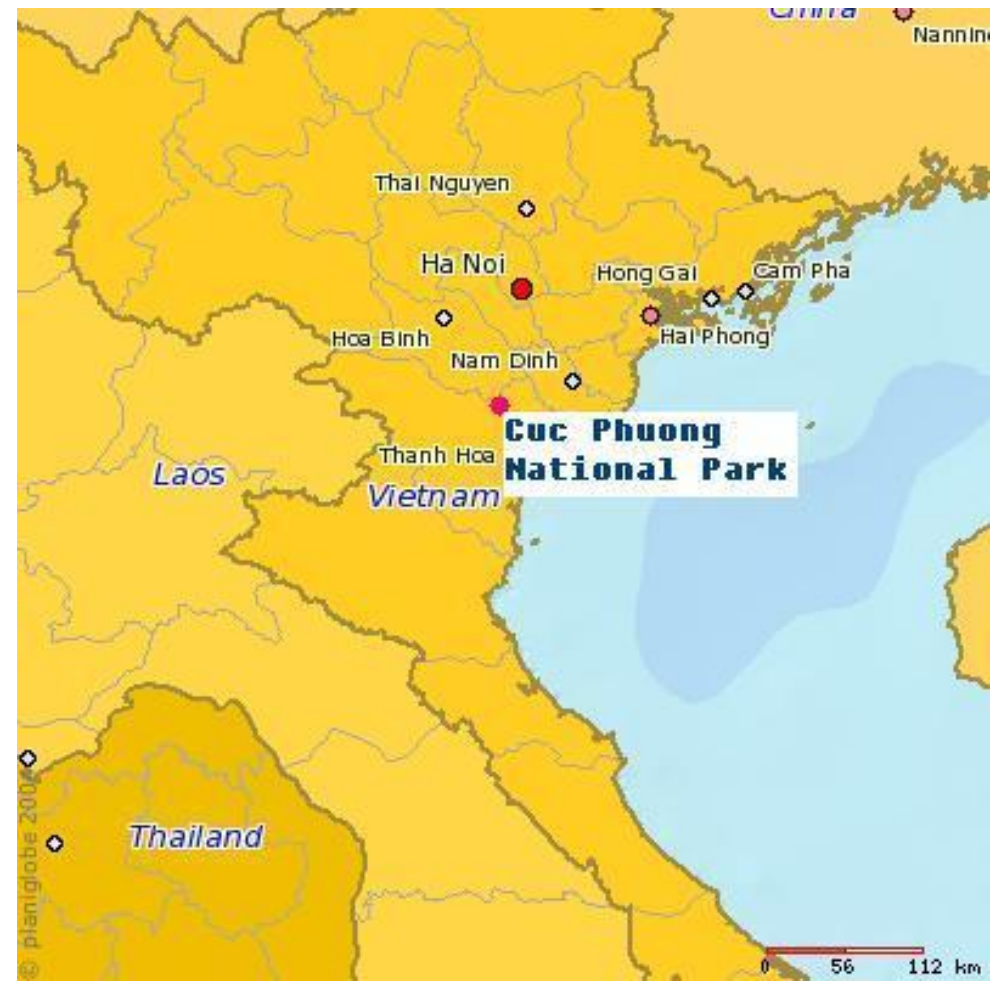

Figure 2. Location of Cuc Phuong National Park Source: http://wikitravel.org/en/Cuc_Phuong_National_Park (2008)

Population and sampling unit

According to the CPNP statistics (2004), CPNP extends over three provinces (Figures 2, 3); it covers 4 districts containing 14 communes and a population of 68,828 inhabitants. However, there are only 5 communes (with 8 hamlets) located wholly or partly within the boundaries of the park, accounting for a total park population of 2,200 residents.

Due to a limited financial budget and time constraints, it was decided that the surveys would be conducted using a manageable method. Specifically, the study only included the five communes located wholly or partly within the boundaries of CPNP (see Figure 3) namely Cuc Phuong, Yen Quang, Yen Tri, An Nghia, and Thach Lam communes as its primary sampling unit. These communes are located in the areas where tourism activities occur (in the form of informal settlements, restaurants, hotels, guesthouses, homestays, etc.). Residents living in these areas include both those who earn an income from tourism and those who are not involved in tourism.

\section{Sample size and sampling technique}

Since the data regarding the population size has not been recently updated, the research surmised that the actual park population could be far above the abovementioned figure of 2,200 residents (about 3000 residents); hence, it was decided that the representative sample size would comprise approximately 220 - 300 residents, or equal to $10 \%$ of the total population of the study area (Krejcie \& Morgan, 1970, cited in Jennings, 2001: 148).

A combination of systematic and stratified ramdom sampling approaches was employed for the sample selection.Decisions regarding the number of resident to sample at each commune were based on the following formula: 


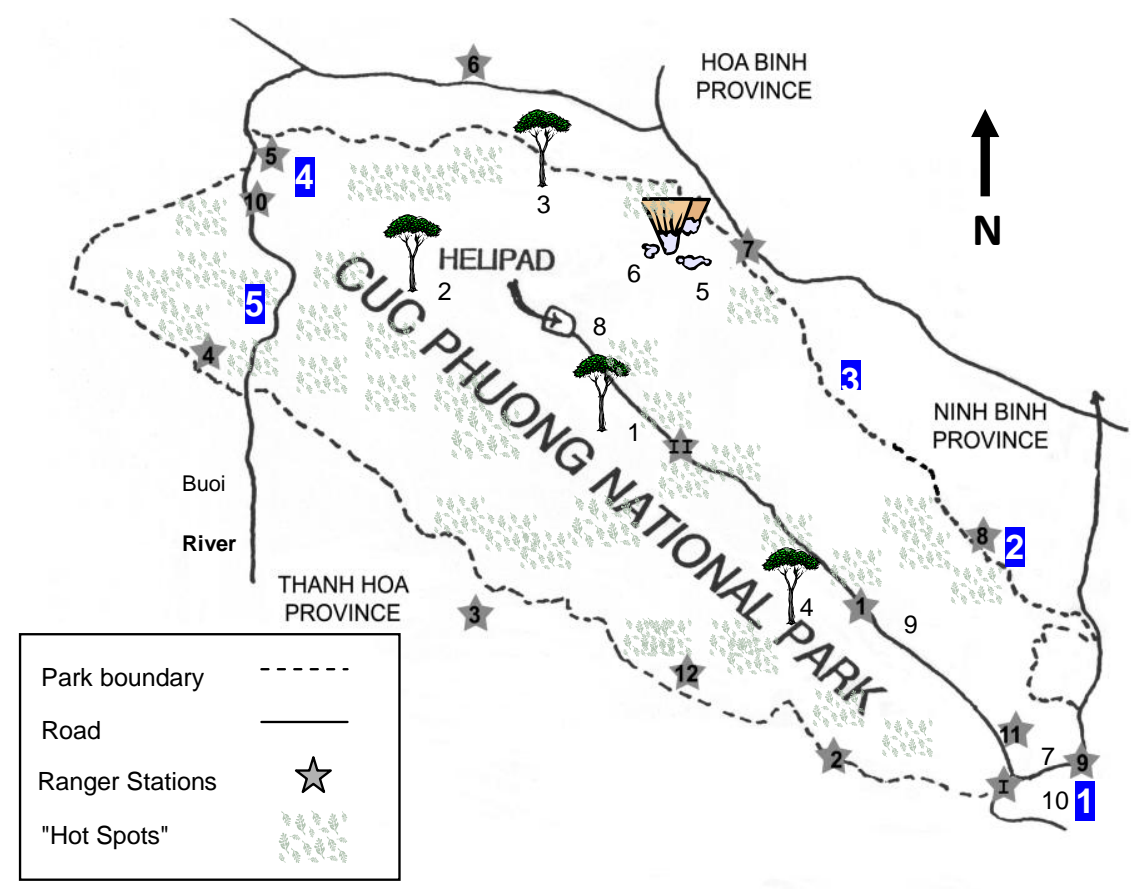

Figure 3. Cuc Phuong study areas

Note: 1.Cuc Phuong Commune; 2. Yen Quang Commune; 3. Yen Tri Commune; 4.An Nghia Commune; 5.Thach Lam Commune.

Communes $=5=\mathrm{k}$

$\mathrm{n}=250$ households

$\mathrm{n} / \mathrm{k}=250 / 5=50$

Therefore, 50 households in each commune were approached to participate in this study, after which they were sent the survey questionnaires. In this manner, a total of 250 households were contacted, with 238 individuals agreeing to participate; this indicates a response rate of $95.2 \%$. Most of the questionnaires were completed in the presence the survey teams, while some were left with the respondent and were collected either later that day or on the following day.

The returned questionnaires with missing data were eliminated from the analysis, because any statistical result based on a data set with missing values would be biased to the extent that the variables included in the analysis are influenced by the missing data process. Following this elimination process, a total of
201 response questionnaires with complete data were retained for the analysis, which indicates a response rate of $80.4 \%$.

\section{Findings and discussion \\ Profile of the respondents}

The sample appeared to suitable represent the population in terms of thedemographic profiles of the respondents, which are presented in Table 1.

The study's participants were mostly male $(62.7 \%)$, concentrated in the $26-55$ years age group $(69.1 \%)$. The majority of respondents were married (81.1\%), born in CPNP $(67.2 \%)$, and from the Muong ethnic group (65.7\%). A large section of the sample $(77.1 \%)$ had jobs that were not related to tourism, and $65.2 \%$ of the total respondents had been living in the area for over 20 years. In terms of education level, there was a concentration at the secondary and high school level ( $32.8 \%$ and $21.9 \%$, respectively ); college graduates 
Table 1. Profile of the respondents

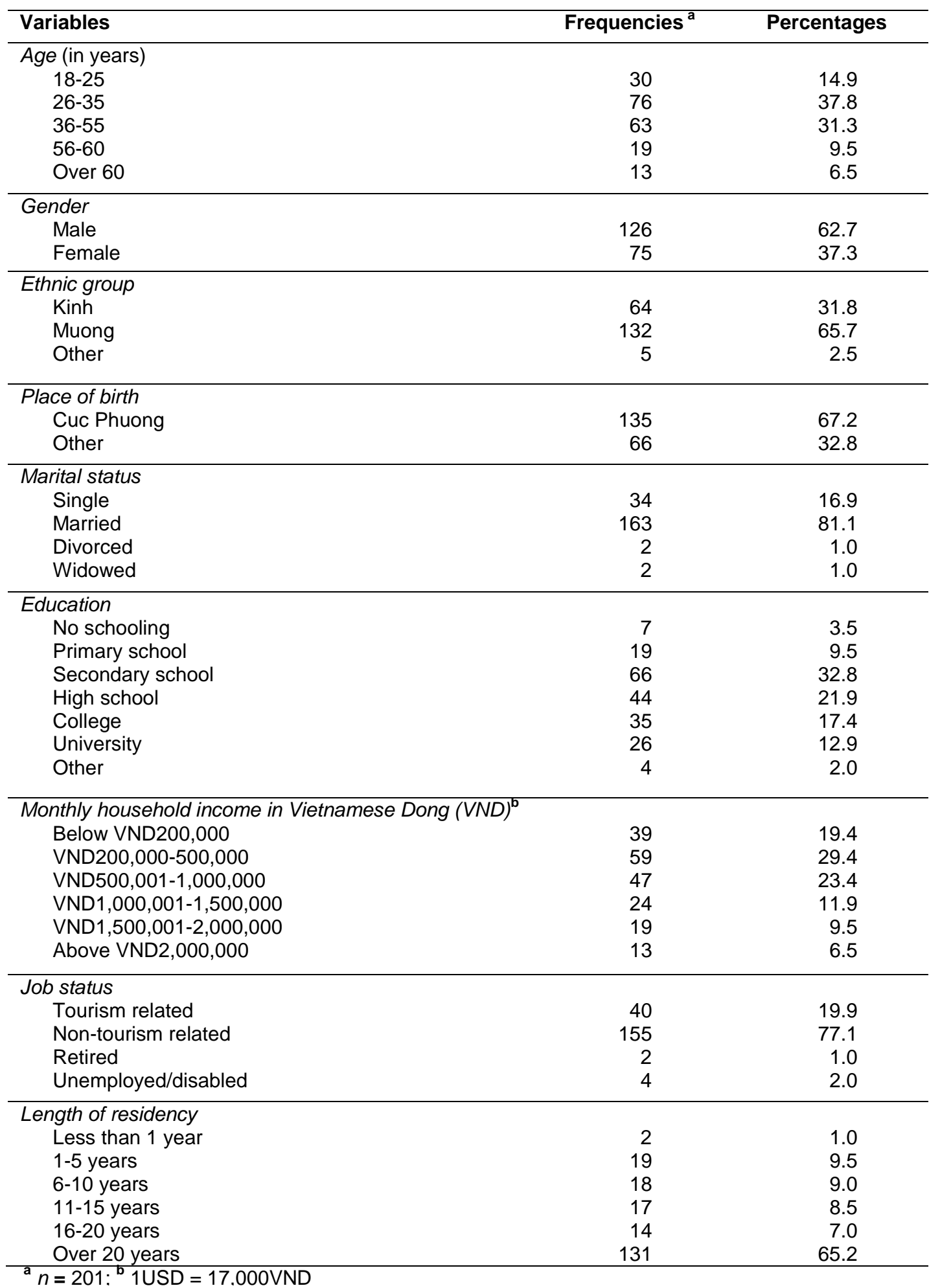


constituted $17.4 \%$ of the sample, and $12.9 \%$ had completed university-level education. The monthly household income of the majority of respondents (84.1\%) was below 1,500,000 Vietnamese Dong (VND).

\section{Perception towards tourism}

Table 2 and Figure 4 present the responses to the 43 perception-related statements. The survey questionnaire was divided into six subsections, based on three categories of tourism impact: positive/negative economic impacts, positive/negative socio-cultural impacts, and positive/negative environmental impacts. In addition, the respondents were asked to evaluate the overall impact of tourism in CPNP, and to indicate their support for tourism development in CPNP.

In general, the results of this study indicate that the CPNP residents tend to have positive perceptions of tourism impacts. Remarkably, respondents agreed to all the positive statements. They especially felt that tourism had improved the quality of products and services $(m=4.0896)$ in that region, increased residents' pride in the local culture $(m=4.0547)$, contributed to the preservation of the natural environment and protection of wildlife in CPNP $(m=3.8856)$, and provided an incentive for the

Table 2. Tourism Perception Items and Composite Scales

\begin{tabular}{|c|c|c|c|c|c|c|c|}
\hline Items & $1(\%)$ & $2(\%)$ & $3(\%)$ & $4(\%)$ & $5(\%)$ & Mean $^{\mathrm{a}}$ & $S D$ \\
\hline \multicolumn{8}{|l|}{ Positive economic impacts } \\
\hline $\begin{array}{l}\text { Tourism has improved employment opportunities in my } \\
\text { community. }\end{array}$ & 8.5 & 16.9 & 16.4 & 43.8 & 14.4 & 3.3881 & 1.17416 \\
\hline $\begin{array}{l}\text { Our standard of living has increased considerably } \\
\text { because of tourism. }\end{array}$ & 12.4 & 18.4 & 23.9 & 35.3 & 10.0 & 3.1194 & 1.19401 \\
\hline $\begin{array}{l}\text { Tourism has attracted more investment to my } \\
\text { community }\end{array}$ & 2.0 & 13.9 & 33.3 & 32.8 & 17.9 & 3.5075 & 1.00558 \\
\hline $\begin{array}{l}\text { The quality of public services in the village is now better } \\
\text { due to tourism investment. }\end{array}$ & 2.0 & 10.4 & 22.9 & 42.8 & 21.9 & 3.7214 & 0.98590 \\
\hline $\begin{array}{l}\text { Tourism is one of the most important industries } \\
\text { supporting the local economy. }\end{array}$ & 5.5 & 10.0 & 28.9 & 42.3 & 13.4 & 3.4826 & 1.02516 \\
\hline $\begin{array}{l}\text { Tourism creates new business opportunities for local } \\
\text { residents. }\end{array}$ & 5.0 & 10.9 & 20.4 & 42.8 & 20.9 & 3.6368 & 1.08279 \\
\hline \multicolumn{8}{|l|}{ Negative economic impacts } \\
\hline $\begin{array}{l}\text { Tourism income generated in the area goes to outside } \\
\text { organizations and individuals. }\end{array}$ & 13.9 & 25.4 & 32.3 & 19.9 & 8.5 & 2.8358 & 1.15235 \\
\hline $\begin{array}{l}\text { Income from tourism benefits only a few people in this } \\
\text { community. }\end{array}$ & 6.5 & 28.4 & 24.4 & 28.4 & 12.4 & 3.1194 & 1.14703 \\
\hline $\begin{array}{l}\text { The prices of many goods and services in the } \\
\text { community have increased because of tourism. }\end{array}$ & 4.0 & 14.9 & 15.4 & 39.3 & 26.4 & 3.6915 & 1.13330 \\
\hline $\begin{array}{l}\text { Real estate prices in the community have increased } \\
\text { because of tourism. }\end{array}$ & 3.5 & 3.0 & 17.4 & 36.8 & 39.3 & 4.0547 & 1.00099 \\
\hline $\begin{array}{l}\text { Seasonal tourism has created high-risk, under-or } \\
\text { unemployment issues. }\end{array}$ & 14.9 & 21.4 & 44.3 & 15.9 & 3.5 & 2.7164 & 1.01695 \\
\hline $\begin{array}{l}\text { Tourism development in CPNP interferes with the } \\
\text { residents' daily economic activities. }\end{array}$ & 18.4 & 37.3 & 25.9 & 11.4 & 7.0 & 2.5124 & 1.12743 \\
\hline \multicolumn{8}{|l|}{ Positive socio-cultural impacts } \\
\hline $\begin{array}{l}\text { Tourism has improved the quality of products and } \\
\text { services of tourism infrastructure such as roads, } \\
\text { transportation systems, restaurants, shops, and guest- } \\
\text { houses in the area. }\end{array}$ & 1.5 & 4.0 & 14.4 & 44.3 & 35.8 & 4.0896 & 0.88991 \\
\hline $\begin{array}{l}\text { Tourism has increased residents' pride in the local } \\
\text { culture of the community. }\end{array}$ & 1.0 & 1.5 & 18.4 & 49.3 & 29.9 & 4.0547 & 0.79498 \\
\hline $\begin{array}{l}\text { Tourism encourages a wide variety of cultural activities } \\
\text { such as crafts, art, and music in the community. }\end{array}$ & 1.5 & 11.4 & 24.4 & 47.3 & 15.4 & 3.6368 & 0.92868 \\
\hline $\begin{array}{l}\text { Tourism helps keep culture alive and helps maintain the } \\
\text { ethnic identity of the local residents. }\end{array}$ & 0.5 & 6.0 & 21.4 & 50.7 & 21.4 & 3.8657 & 0.83478 \\
\hline $\begin{array}{l}\text { Tourism has resulted in more cultural exchange } \\
\text { between tourists and residents. }\end{array}$ & 2.5 & 5.5 & 18.9 & 48.8 & 24.4 & 3.8706 & 0.92908 \\
\hline $\begin{array}{l}\text { Owing to tourism development, local people now have } \\
\text { more recreational opportunities. }\end{array}$ & 5.0 & 13.9 & 19.9 & 42.3 & 18.9 & 3.5622 & 1.09880 \\
\hline
\end{tabular}




\section{Negative socio-cultural impacts}

Local residents have suffered by living in a tourism destination area.

Tourism damages to the local culture.

Tourism encourages residents to imitate the behavior of the tourists and relinquish cultural traditions.

The increase in tourist numbers has led to alienation between tourists and residents.

It is becoming increasingly difficult to find a quiet place for recreation around here because of tourists.

Tourism has limited the use of recreational facilities such as entertainment and recreational centers, and sport complexes for the local people.

Tourism contributes to social problems such as crime, drug use, prostitution, alcoholism, gambling, smuggling, and so on in the community.

\section{Positive environmental impacts}

Tourism has contributed to the preservation of the natural environment and protection of wildlife in CPNP.

Tourism has improved the ecological environment of the community in many ways.

$\begin{array}{rrrrrrr}17.4 & 32.3 & 24.9 & 20.9 & 4.5 & 2.6269 & 1.12919 \\ 27.4 & 40.8 & 21.4 & 8.5 & 2.0 & 2.1692 & 0.99058 \\ 13.9 & 31.3 & 21.4 & 27.4 & 6.0 & 2.8010 & 1.16198 \\ 18.9 & 33.8 & 29.9 & 13.4 & 4.0 & 2.4975 & 1.06829 \\ 23.9 & 30.8 & 23.4 & 15.9 & 6.0 & 2.4925 & 1.18794 \\ 18.9 & 38.3 & 30.3 & 9.5 & 3.0 & 2.3930 & 0.99486 \\ & & & & & & \\ 20.4 & 21.9 & 22.4 & 26.9 & 8.5 & 2.8109 & 1.27046\end{array}$

Tourism has improved the area's appearance (visual and aesthetic).

Tourism provides an incentive for the restoration of historic buildings.

\section{Negative environmental impacts}

The construction of hotels and other tourist facilities have destroyed the natural environment in the region.

Tourism has negative impacts on the natural resources (including the collection of plants, animals, rocks, or artifacts by or for tourists).

Tourism has created significant solid waste and air, water, noise, and soil pollution.

Because of tourism, there now are fewer natural landscapes and agricultural lands in the area.

Tourism facilities built in and around CPNP are not in harmony with the natural environment and traditional architecture.

$\begin{array}{lllllll}2.5 & 7.0 & 21.4 & 37.8 & 31.3 & 3.8856 & 1.01086 \\ 2.0 & 4.5 & 33.3 & 40.3 & 19.9 & 3.7164 & 0.90232 \\ 2.5 & 8.5 & 25.9 & 45.8 & 17.4 & 3.6716 & 0.94427 \\ 0.5 & 7.5 & 31.8 & 38.3 & 21.9 & 3.7363 & 0.90284\end{array}$

$\begin{array}{rrrrrrr}13.4 & 36.8 & 30.3 & 16.4 & 3.0 & 2.5871 & 1.01175 \\ 11.9 & 23.9 & 25.9 & 22.9 & 15.4 & 3.0597 & 1.25157 \\ 18.9 & 24.9 & 12.9 & 34.3 & 9.0 & 2.8955 & 1.30538 \\ 6.5 & 21.9 & 20.9 & 36.3 & 14.4 & 3.3035 & 1.15431 \\ 12.4 & 28.4 & 34.8 & 19.4 & 5.0 & 2.7612 & 1.05957\end{array}$

\section{Evaluation of tourism impacts}

Overall, I believe that the benefits of tourism exceed the cost to the people of the CPNP.

I think tourism development in CPNP brings more benefit than harm..

I think tourism development in CPNP produces more negative impacts than positive impacts.

\section{Support for tourism development}

I would like to see more tourists in CPNP.

The government should increase its efforts to provide infrastructure to support tourism development in CPNP.

The government should control tourism development in CPNP in order to maximize the benefits and minimize the cost of the development.

The community should support tourism development in this area.

I am willing to be a part of tourism planning for CPNP in the future.

I am willing to be involved in the development of CPNP for ecotourism in the future.

\begin{tabular}{rrrrrrr}
4.5 & 14.4 & 16.4 & 50.7 & 13.9 & 3.5522 & 1.04332 \\
0.5 & 11.4 & 5.5 & 56.2 & 26.4 & 3.9652 & 0.90762 \\
23.4 & 58.2 & 6.0 & 9.0 & 3.5 & 2.1095 & 0.97875 \\
\hline 1.5 & 4.5 & 16.4 & 45.3 & 32.3 & 4.0249 & 0.89687 \\
0.5 & 3.0 & 17.4 & 54.7 & 24.4 & 3.9950 & 0.76484 \\
1.0 & 10.4 & 25.4 & 37.3 & 25.9 & 3.7662 & 0.98491 \\
0 & 2.5 & 9.5 & 51.2 & 36.8 & 4.2239 & 0.71737 \\
4.5 & 4.0 & 14.4 & 50.7 & 26.4 & 3.9055 & 0.98286 \\
4.0 & 3.5 & 10.4 & 43.3 & 38.8 & 4.0945 & 0.99299
\end{tabular}

${ }^{\text {a }} n=201 ; 1$ = strongly disagree to 5 = strongly agree 
restoration of historic buildings ( $m=3.7363$ ). The respondents also agreed that tourism has positive economic impacts, but the mean scores for this aspect (ranging from $m=3.1194$ to $m=3.7214$ ) were not as high as those for positive socio-cultural and environmental impacts. Meanwhile, the respondents in their statements expressed their concerns over the fact that the prices of real estate, and many goods and services in their community have increased because of tourism ( $m=4.0547$ and $m=3.6915$ ), and that the income from tourism is not distributed equally among residents in their community ( $m=3.1194)$. They agreed, albeit to a very slight extent that the natural landscapes and agricultural lands in their area had diminished in recent years because of tourism $(m=3.3035)$, and that tourism has had some negative impacts on the natural resources $(m=3.0597)$. The respondents also tended to disagree with the statement that tourism is damaging their culture $(m=2.1692)$, and has limited their use of recreational facilities $(m=2.3930)$. The respondents, however, indicated uncertainty in nearly all the statements regarding the negative impacts of tourism, especially those related to the sociocultural impacts of tourism.

In line with the findings by Tatoglu et al.(2000), Andriotis (2004), and Kuvan \& Akan (2005), the present study found that the CPNP residents strongly agreed that tourism creates positive socio-cultural and environmental impacts. However, contrary to the findings of those earlier studies, which suggest that residents value positive economic impacts the most, the CPNP residents tended to value positive sociocultural as well as environmental impacts more, while ascribing a higher score to the latter aspect.

Another prominent finding of this study suggests that support for tourism development in CPNP is strong among its residents. They firmly believe that their community should support tourism development and are willing not only to be personal involved in the future development of ecotourism in CPNP, but also to welcome more tourists ( $m=4.2239$, $m=4.0945$, and $m=4.0249$, respectively).
These findings are similar to those of other studies such as Milman and Pizam (1988), King, Pizam, and Milman (1993), Haralambopoulos and Pizam (1996), and Rátz (2000), whereby the respondents not only support the current extent of tourism, but also look forward for its expansion.

\section{Difference in perceptions among residents}

A series of ANOVAs and $t$-tests was conducted to examine the differences in perceptions among respondents with different sociodemographic characteristics towards tourism impact, their overall evaluation of the impacts and their support for tourism development in CPNP.

The findings of this study revealed that sociodemographic characteristics significantly influence residents' perceptions of tourism impacts, evaluation of tourism impacts, and their support for tourism development. However, perceptions of CPNP residents differed according to nine socio-demographic characteristics.

Similar to findings by Kuvan and Akan (2005) among residents in Belek, Turkey, but contrary to findings by Kayat (2000) among residents in Langkawi, monthly household income was the most significant variable affecting CPNP residents' perceptions of tourism impacts, evaluation of tourism impacts and their support for tourism development (Table 3). The result of this study shows that, generally, CPNP residents who had average and higher income were likely to favor tourism and supported tourism development. In contrast, residents who had lower income seemed to value tourism lower and were less supportive tourism development. This result has helped to confirm the usefulness of social exchange theory in explaining residents' perceptions of tourism as there are indications that those residents who benefit economically from tourism are supportive of it. This result is also useful to confirm that residents' perceptions towards tourism development are context-specific. 


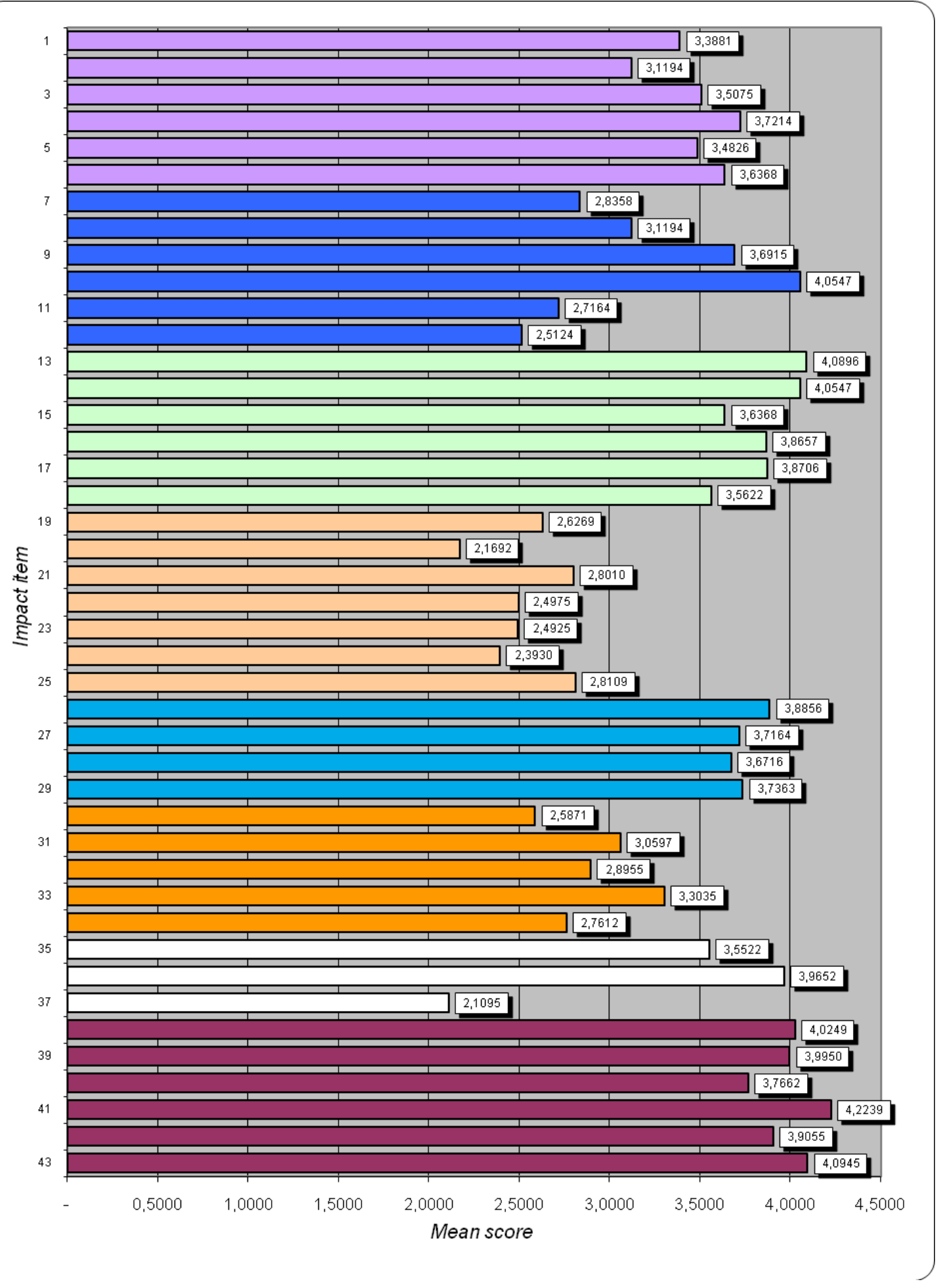

Figure 4. Mean scores of respondents' ratings 
Items

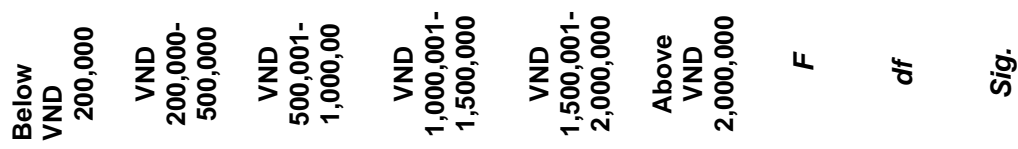

Tourism has improved employment opportunities in my community

Our standard of living has increased considerably because of tourism

Tourism has attracted more investment to my community

Tourism is one of the most important industries supporting the local economy

Tourism creates new business opportunities for local residents

Real estate prices in the community have increased because of tourism

Tourism development in CPNP interferes with the residents' daily economic activities

Tourism has improved the quality of products and services of tourism infrastructure such as roads, transportation system, restaurants, shops, and guest-house in the area

Tourism has increased residents' pride in the local culture of the community

Tourism helps keep culture alive and helps maintain the ethnic identity of the local residents

Tourism has resulted in more cultural exchange between tourists and residents

Owing to tourism development, local people now have more recreational opportunities

Tourism damages to the local culture

Tourism encourages residents to imitate the behavior of the tourists and relinquish cultural traditions

The increase in tourist numbers has led to alienation between tourists and residents

Tourism contributes to social problems such as crime, drug use, prostitution, alcoholism, gambling, smuggling, and so on in the community

Tourism has improved the ecological environment of the community in many ways

Tourism has improved the area's appearance

Tourism has created significant solid waste and air, water, noise, and soil pollution

Because of tourism, there are now less of natural landscapes and agricultural lands in the area

Overall, I believe that the benefits of tourism exceed the cost to the people of the CPNP

I would like to see more tourists in CPNP 136

\begin{tabular}{|c|c|c|c|c|c|c|c|c|}
\hline $3.08^{5}$ & $2.97^{5,6}$ & 3.53 & 3.75 & $4.05^{1,2}$ & $4.08^{2}$ & 5.294 & 195 & 0.000 \\
\hline 3.05 & $2.61^{3,5,6}$ & $3.32^{2}$ & 3.17 & $3.74^{2}$ & $3.92^{2}$ & 5.113 & 195 & 0.000 \\
\hline $3.26^{4}$ & $3.24^{4}$ & 3.62 & $4.04^{1,2}$ & 3.74 & 3.77 & 3.366 & 195 & 0.006 \\
\hline 3.38 & $3.08^{4,5}$ & 3.57 & $3.96^{2}$ & $3.79^{2}$ & 3.92 & 4.068 & 195 & 0.002 \\
\hline 3.49 & $3.29^{3,5}$ & $3.87^{2}$ & 3.75 & $4.05^{2}$ & 4.00 & 2.849 & 195 & 0.017 \\
\hline $3.54^{2,3}$ & $4.20^{1}$ & $4.15^{1}$ & 4.13 & 4.11 & 4.38 & 2.861 & 195 & 0.016 \\
\hline $2.95^{3,4}$ & 2.71 & $2.19^{1}$ & $2.04^{1}$ & 2.32 & 2.62 & 3.476 & 195 & 0.005 \\
\hline $3.62^{3,4,5,6}$ & 3.98 & $4.28^{1}$ & $4.33^{1}$ & $4.37^{1}$ & $4.46^{1}$ & 4.317 & 195 & 0.001 \\
\hline $3.92^{5}$ & $3.69^{3,4,5}$ & $4.21^{2}$ & $4.42^{2}$ & $4.42^{1,2}$ & 4.31 & 5.658 & 195 & 0.000 \\
\hline 3.74 & $3.53^{3,4,5}$ & $4.15^{2}$ & $4.13^{2}$ & $4.26^{2}$ & 3.69 & 5.126 & 195 & 0.000 \\
\hline $3.62^{3,5}$ & $3.61^{3,5}$ & $4.21^{1,2}$ & 3.96 & $4.32^{1,2}$ & 3.77 & 4.019 & 195 & 0.002 \\
\hline 3.41 & $3.27^{5}$ & 3.66 & 3.75 & $4.05^{2}$ & 3.92 & 2.301 & 195 & 0.046 \\
\hline 2.23 & 2.44 & 1.89 & 2.13 & 2.26 & 1.69 & 2.369 & 195 & 0.041 \\
\hline 2.67 & $3.24^{3}$ & $2.49^{2}$ & 2.58 & 2.74 & 2.85 & 2.742 & 195 & 0.020 \\
\hline 2.49 & $2.93^{3,6}$ & $2.32^{2}$ & 2.42 & 2.21 & $1.77^{6}$ & 4.007 & 195 & 0.002 \\
\hline $2.26^{2}$ & $3.27^{1,3}$ & $2.47^{2}$ & 3.08 & 2.68 & 3.31 & 4.790 & 195 & 0.000 \\
\hline $3.54^{6}$ & $3.75^{6}$ & $3.49^{6}$ & 3.96 & $3.63^{6}$ & $\operatorname{li}_{3,5}^{62^{1,2}}$ & 4.178 & 195 & 0.001 \\
\hline 3.44 & $3.42^{4}$ & 3.70 & $4.08^{2}$ & 4.11 & 4.00 & 3.550 & 195 & 0.004 \\
\hline $2.31^{3,4}$ & 3.00 & $3.09^{1}$ & $3.21^{1}$ & 3.16 & 2.54 & 2.577 & 195 & 0.028 \\
\hline 3.00 & 3.68 & 3.13 & 3.63 & 2.95 & 3.08 & 2.973 & 195 & 0.013 \\
\hline $3.31^{5}$ & $3.32^{5}$ & 3.70 & 3.63 & $4.11^{1,2}$ & 3.85 & 2.594 & 195 & 0.027 \\
\hline $3.74^{5}$ & $3.78^{5}$ & 4.21 & 4.21 & $4.47^{1,2}$ & 4.31 & 3.708 & 195 & 0.003 \\
\hline
\end{tabular}


The government should increase its efforts to provide infrastructure to support tourism development in CPNP

The community should support tourism development in this area

I am willing to be a part of tourism planning for CPNP in the future

I am willing to be involved in the development of CPNP for ecotourism in the future

$\begin{array}{ccccccccc}3.72 & 3.90 & 4.15 & 4.25 & 4.16 & 4.00 & 2.378 & 195 & 0.040 \\ 3.97 & 4.14 & 4.34 & 4.29 & 4.42 & 4.54 & 2.270 & 195 & 0.049 \\ 3.44^{3,4,5} & 3.64^{3,5} & 4.19^{1,2} & 4.21^{1} & 4.32^{1,2} & 4.31 & 5.526 & 195 & 0.000 \\ 3.69^{3,5} & 3.86^{3} & 4.43^{1,2} & 4.29 & 4.42^{1} & 4.31 & 3.949 & 195 & 0.002\end{array}$

Superscript numbers indicate that mean values are significantly different from the mean values in the equivalent columns. Numbers denote columns 2-7, i.e. 1=Below VND200,000; 2=VND200,000-VND500,000; 3=VND500,001-VND1,000,000; 4=VND1,000,001-VND1,500,000; 5=VND1,500,001-VND2,000,000; 6=Above VND2,000,000. For example, the first line reads that significant differences existed between those that earn below VND200,000 and those that earn VND1,500,001VND2,000,000; between those that earn VND200,000-VND500,000 and those that earn VND1,500,001-VND2,000,000; and those that earn VND200,000-VND500,000 and those that earn above VND2,000,000.

Table 4. Results of $t$-test for Ethnic groups

\begin{tabular}{|c|c|c|c|c|c|c|}
\hline Items & $\begin{array}{l}\text { Overall } \\
\text { mean } \\
\text { score }\end{array}$ & Kinh & $\begin{array}{l}\text { Muong } \\
\text { and } \\
\text { others }\end{array}$ & $t$ & $D f$ & Sig. \\
\hline $\begin{array}{lll}\text { Tourism has } & \text { improved } & \text { employment } \\
\text { opportunities in my community } & \end{array}$ & 3.39 & 3.94 & 3.13 & 5.234 & 155.69 & 0.000 \\
\hline $\begin{array}{l}\text { Our standard of living's increased considerably } \\
\text { because of tourism }\end{array}$ & 3.12 & 3.64 & 2.88 & 4.840 & 155.19 & 0.000 \\
\hline $\begin{array}{l}\text { Tourism has attracted more investment to my } \\
\text { community }\end{array}$ & 3.51 & 3.75 & 3.39 & 2.364 & 199 & 0.019 \\
\hline $\begin{array}{l}\text { Tourism is one of the most important industries } \\
\text { supporting the local economy }\end{array}$ & 3.48 & 3.69 & 3.39 & 2.068 & 143.04 & 0.040 \\
\hline $\begin{array}{l}\text { Tourism creates new business opportunities for } \\
\text { local residents }\end{array}$ & 3.64 & 3.86 & 3.53 & 2.110 & 139.95 & 0.037 \\
\hline $\begin{array}{l}\text { Real estate prices in the community have } \\
\text { increased because of tourism }\end{array}$ & 4.05 & 4.31 & 3.93 & 3.007 & 186.85 & 0.003 \\
\hline $\begin{array}{l}\text { Tourism development in CPNP interferes with } \\
\text { the residents' daily economic activity }\end{array}$ & 2.51 & 2.25 & 2.63 & -2.279 & 199 & 0.024 \\
\hline $\begin{array}{l}\text { Tourism has increased residents' pride in the } \\
\text { local culture in the community }\end{array}$ & 4.05 & 4.28 & 3.95 & 2.808 & 199 & 0.005 \\
\hline $\begin{array}{l}\text { Tourism helps keep culture alive and helps } \\
\text { maintain the ethnic identity }\end{array}$ & 3.87 & 4.08 & 3.77 & 2.713 & 152.05 & 0.007 \\
\hline $\begin{array}{l}\text { Owing to tourism, local people have more } \\
\text { recreation opportunities }\end{array}$ & 3.56 & 3.81 & 3.44 & 2.459 & 158.15 & 0.015 \\
\hline $\begin{array}{l}\text { Local residents have suffered by living in a } \\
\text { tourism destination area }\end{array}$ & 2.63 & 2.30 & 2.78 & -2.883 & 199 & 0.004 \\
\hline Tourism damages to the local culture & 2.17 & 1.92 & 2.28 & -2.449 & 199 & 0.015 \\
\hline $\begin{array}{l}\text { The increase in tourism numbers has led to } \\
\text { alienation between tourists and residents }\end{array}$ & 2.50 & 2.23 & 2.62 & -2.632 & 153.36 & 0.009 \\
\hline $\begin{array}{l}\text { Tourism has limited the use of the recreational } \\
\text { facilities like entertainment and recreation } \\
\text { centers, sport complex by local people }\end{array}$ & 2.39 & 2.16 & 2.50 & -2.548 & 154.51 & 0.012 \\
\hline $\begin{array}{l}\text { Tourism has improved the area's appearance } \\
\text { (visual and aesthetic) }\end{array}$ & 3.67 & 4.00 & 3.52 & 3.483 & 125.11 & 0.001 \\
\hline $\begin{array}{l}\text { Overall, I believe that the benefits of tourism } \\
\text { exceed the cost to the people of the CPNP }\end{array}$ & 3.55 & 3.94 & 3.37 & 4.273 & 177.51 & 0.000 \\
\hline $\begin{array}{l}\text { I think tourism development in CPNP brings } \\
\text { more benefit than harm. }\end{array}$ & 3.96 & 4.16 & 3.88 & 2.056 & 199 & 0.041 \\
\hline I would like to see more tourists in CPNP & 4.02 & 4.31 & 3.89 & 3.670 & 176.41 & 0.000 \\
\hline $\begin{array}{l}\text { The government should increase their effort in } \\
\text { providing infrastructure to support tourism } \\
\text { development }\end{array}$ & 3.99 & 4.17 & 3.91 & 2.264 & 199 & 0.025 \\
\hline $\begin{array}{l}\text { I am willing to be a part of tourism planning in } \\
\text { CPNP in the future }\end{array}$ & 3.91 & 4.17 & 3.78 & 3.084 & 177.02 & 0.002 \\
\hline
\end{tabular}


Other socio-demographic characteristics found to explain CPNP residents' perception towards tourism development are ethnicity (Table 4), education level (Table 5), job status (Table 6), age (Table 7).
Those residents belonging to Kinh group have more positive views towards tourism's positive impacts, and they also support tourism development more compared to the residents belonging to Muong and others ethnic groups.

Table 5. Results of ANOVA for levels of Education

Items

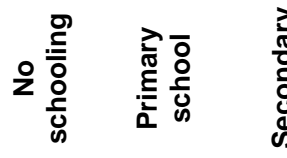

Tourism has improved employment opportunities in my community

Our standard of living has increased considerably because of tourism

The quality of public services in the village is now better due to tourism investment

Tourism is one of the most important industries supporting the local economy

Tourism creates new business opportunities for local residents

Tourism development in CPNP interferes with the residents' daily economic activities

Tourism has increased residents' pride in the local culture of the community

Tourism helps keep culture alive and helps maintain the ethnic identity of the local residents

Tourism has resulted in more cultural exchange between tourists and residents

Owing to tourism development, local people now have more recreational opportunities

Local residents have suffered by living in a tourism destination area

Tourism encourages residents to imitate the behavior of the tourists and relinquish cultural traditions

The increase in tourist numbers has led to alienation between tourists and residents

Tourism has improved the area's appearance

Because of tourism, there are now less of natural landscapes and agricultural lands in the area

Overall, I believe that the benefits of tourism exceed the cost to the people of the CPNP

I would like to see more tourists in CPNP

I am willing to be a part of tourism planning for CPNP in the future

I am willing to be involved in the development of CPNP for ecotourism in the future

$\begin{array}{lcccccccc}2.43 & 2.05^{3,4.5,6} & 3.26^{2,5} & 3.55^{2} & 3.91^{2,3} & 3.90^{2} & 10.869 & 195 & 0.000 \\ 2.43 & 2.21^{3,4,5,6} & 3.09^{2} & 3.14^{2} & 3.40^{2} & 3.57^{2} & 4.223 & 195 & 0.001 \\ 3.57 & 3.00^{3,4,6} & 3.86^{2} & 3.77^{2} & 3.71 & 3.83^{2} & 2.537 & 195 & 0.030 \\ 2.71 & 2.68^{5,6} & 3.48 & 3.50 & 3.74^{2} & 3.83^{2} & 4.633 & 195 & 0.001 \\ 3.29 & 2.89^{5,6} & 3.65 & 3.66 & 3.89^{2} & 3.83^{2} & 2.606 & 195 & 0.026 \\ 3.00 & 2.89 & 2.65^{5} & 2.55 & 2.00^{3} & 2.40 & 2.504 & 195 & 0.032 \\ 4.00 & 3.58^{5,6} & 4.09 & 3.82^{5} & 4.37^{2,4} & 4.27^{2} & 3.989 & 195 & 0.002 \\ 4.00 & 3.21^{3,5,6} & 3.98^{2} & 3.68 & 4.11^{2} & 3.97^{2} & 4.072 & 195 & 0.002 \\ 3.29 & 3.32^{5} & 3.91 & 3.89 & 4.20^{2} & 3.87 & 2.953 & 195 & 0.014 \\ 2.86 & 2.42^{3,4,5,6} & 3.61^{2} & 3.59^{2} & 4.00^{2} & 3.80^{2} & 7.010 & 195 & 0.000 \\ 2.71 & 3.32^{5} & 2.64 & 2.75 & 2.20^{2} & 2.48 & 2.767 & 195 & 0.019 \\ 3.86 & 3.42 & 4.30 & 4.02 & 4.23 & 4.30 & 5.488 & 195 & 0.000\end{array}$

Superscript numbers indicate that mean values are significantly different from the mean values in the equivalent columns. Numbers denote columns 2-7, i.e. 1=No schooling, 2=Primary school, 3=Secondary school, 4=High school, 5=College, $6=$ University and others. For example, the first line reads that significant differences existed between those that hold primary school level and those that hold secondary school level, between those that hold primary school level and those that hold high school level, between those that hold primary school level and those that hold college level, between those that hold primary school level and those that hold university or others level, and so forth. 
A closer observation by the researcher reveals that most of Kinh people have tourism relatedjobs. This may help explain why the residents in this group have more positive views than Muong and others.

In addition, those residents with lower level of education (primary school holders in this case) have a critical views about tourism, mainly because they feel that local residents have suffered by living in a tourism destination area, they imitate the behavior of the tourists and relinquish cultural traditions, and tourism reduces the natural landscapes and agricultural lands in their area. They also do not believe that tourism increases the recreation opportunities for the local resident. However, they still believe that benefits of tourism exceed the costs to the people of the CPNP. Those residents holding higher level of education (college level, university and other levels) are likely to enthusiastically welcome tourism. They appreciate tourism's positive impacts, and disapprove of its negative impacts. In this manner, the findings of this study are congruent with the result of study by Haralambopoulos and Pizam (1996), which indicates that the more educated the residents are, the more positive perceptions they have towards tourism. But, these findings contradict the findings of Andriotis (2004) and Kayat (2000), which indicates that highly educated respondents are more likely to express concern about the negative impacts of tourism

Table 6. Results of $t$-test for Job status

\begin{tabular}{|c|c|c|c|c|c|c|}
\hline Items & 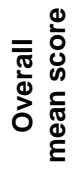 & 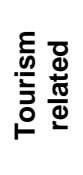 & 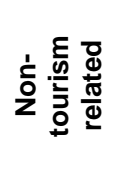 & - & $\frac{5}{0}$ & जं \\
\hline $\begin{array}{lll}\text { Tourism } & \text { has } \quad \text { improved } & \text { employment } \\
\text { opportunities in my community } & \end{array}$ & 3.39 & 4.05 & 3.22 & 5.307 & 90.22 & 0.000 \\
\hline $\begin{array}{l}\text { Our standard of living's increased considerably } \\
\text { because of tourism }\end{array}$ & 3.12 & 3.63 & 2.99 & 3.677 & 79.53 & 0.000 \\
\hline $\begin{array}{l}\text { Tourism income generated in the area goes to } \\
\text { outside organizations and individuals }\end{array}$ & 2.84 & 2.30 & 2.97 & -3.370 & 199 & 0.001 \\
\hline $\begin{array}{l}\text { Income from tourism benefits only a few people } \\
\text { in this community }\end{array}$ & 3.12 & 2.80 & 3.20 & -1.982 & 199 & 0.049 \\
\hline $\begin{array}{l}\text { Tourism development in CPNP interferes with } \\
\text { the residents' daily economic activities }\end{array}$ & 2.51 & 2.03 & 2.63 & -3.296 & 64.28 & 0.002 \\
\hline $\begin{array}{l}\text { Tourism has increased residents' pride in the } \\
\text { local culture of the community }\end{array}$ & 4.05 & 4.40 & 3.97 & 3.136 & 199 & 0.002 \\
\hline $\begin{array}{l}\text { Tourism helps keep culture alive and helps } \\
\text { maintain the ethnic identity of the local } \\
\text { residents }\end{array}$ & 3.87 & 4.08 & 3.81 & 2.026 & 71.92 & 0.046 \\
\hline $\begin{array}{l}\text { Tourism has resulted in more cultural exchange } \\
\text { between tourists and residents }\end{array}$ & 3.87 & 4.13 & 3.81 & 2.573 & 96.54 & 0.012 \\
\hline $\begin{array}{l}\text { Tourism encourages residents to imitate the } \\
\text { behavior of the tourists and relinquish cultural } \\
\text { traditions }\end{array}$ & 2,80 & 2.35 & 2.91 & -2.789 & 199 & 0.006 \\
\hline $\begin{array}{l}\text { The increase in tourist numbers had led to } \\
\text { alienation between tourists and residents }\end{array}$ & 2.50 & 2.10 & 2.60 & -2.669 & 199 & 0.008 \\
\hline $\begin{array}{l}\text { Tourism has limited the use of recreational } \\
\text { facilities such as entertainment and } \\
\text { recreational centers, and sport complexes for } \\
\text { the local people }\end{array}$ & 2.39 & 2.00 & 2.49 & -3.232 & 71.98 & 0.002 \\
\hline $\begin{array}{l}\text { Because of tourism, there are now less of } \\
\text { natural landscapes and agricultural lands in } \\
\text { the area }\end{array}$ & 3.30 & 2.95 & 3.39 & -2.184 & 199 & 0.030 \\
\hline I would like to see more tourists in CPNP & 4.02 & 4.30 & 3.96 & 2.188 & 199 & 0.030 \\
\hline $\begin{array}{l}\text { I am willing to be a part of tourism planning for } \\
\text { CPNP in the future }\end{array}$ & 3.91 & 4.35 & 3.79 & 4.724 & 120.74 & 0.000 \\
\hline $\begin{array}{l}\text { I am willing to be involved in the development of } \\
\text { CPNP for ecotourism in the future }\end{array}$ & 4.09 & 4.40 & 4.02 & 2.195 & 199 & 0.029 \\
\hline
\end{tabular}




\begin{tabular}{|c|c|c|c|c|c|c|c|c|}
\hline Items & $\begin{array}{l}\stackrel{L}{W} \\
\stackrel{\infty}{\leftarrow}\end{array}$ & 卢 & $\begin{array}{l}\text { L̊ } \\
\text { 仓્ల }\end{array}$ & 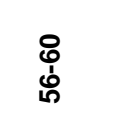 & $\begin{array}{l}\text { ৫ } \\
\text { ठ̀ }\end{array}$ & 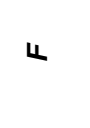 & t & $\stackrel{\infty}{\infty}$ \\
\hline $\begin{array}{l}\text { Tourism has improved employment } \\
\text { opportunities in my community }\end{array}$ & 3.27 & $3.67^{4}$ & $3.51^{4}$ & $2.47^{2,3}$ & 2.77 & 5.604 & 196 & 0.000 \\
\hline $\begin{array}{l}\text { Our standard of living has increased } \\
\text { considerably because of tourism }\end{array}$ & 3.01 & 3.20 & $3.40^{4}$ & $2.42^{3}$ & 2.46 & 3.753 & 196 & 0.006 \\
\hline $\begin{array}{l}\text { Tourism has attracted more investment to } \\
\text { my community }\end{array}$ & 3.23 & $3.71^{4}$ & $3.71^{4}$ & $2.74^{2,3}$ & 3.08 & 5.913 & 196 & 0.000 \\
\hline $\begin{array}{l}\text { Tourism is one of the most important } \\
\text { industries supporting the local economy }\end{array}$ & 3.20 & 3.62 & $3.76^{4}$ & $2.79^{3}$ & 3.00 & 5.401 & 196 & 0.000 \\
\hline $\begin{array}{l}\text { Tourism creates new business opportunities } \\
\text { for local residents }\end{array}$ & 3.63 & $3.67^{4}$ & $3.89^{4}$ & $2.84^{2,3}$ & 3.38 & 3.810 & 196 & 0.005 \\
\hline $\begin{array}{l}\text { Tourism income generated in the area goes } \\
\text { to outside organizations and individuals }\end{array}$ & 3.00 & $2.54^{4}$ & 2.84 & $3.37^{2}$ & 3.38 & 3.307 & 196 & 0.012 \\
\hline $\begin{array}{l}\text { Income from tourism benefits only a few } \\
\text { people in this community }\end{array}$ & $2.93^{5}$ & $2.95^{5}$ & 3.08 & 3.58 & $4.08^{1,2}$ & 3.883 & 196 & 0.005 \\
\hline $\begin{array}{l}\text { Tourism has resulted in more cultural } \\
\text { exchange between tourists and residents }\end{array}$ & $3.83^{4}$ & $4.08^{4}$ & $3.89^{4}$ & $2.89^{1,2,3,5}$ & $4.08^{4}$ & 7.160 & 196 & 0.000 \\
\hline $\begin{array}{l}\text { Local residents have suffered by living in a } \\
\text { tourism destination area }\end{array}$ & $2.50^{5}$ & $2.66^{5}$ & $2.51^{5}$ & $2.42^{5}$ & $3.62^{1,2,3,4}$ & 3.053 & 196 & 0.018 \\
\hline $\begin{array}{l}\text { Tourism has improved the area's } \\
\text { appearance (visual and aesthetic) }\end{array}$ & 3.50 & $3.84^{4}$ & $3.79^{4}$ & $3.00^{2,3}$ & 3.46 & 3.909 & 196 & 0.004 \\
\hline I would like to see more tourists in CPNP & 4.00 & $4.30^{4}$ & $4.10^{4}$ & $3.26^{2,3}$ & 3.23 & 9.194 & 196 & 0.000 \\
\hline $\begin{array}{l}\text { I am willing to be a part of tourism planning } \\
\text { for CPNP in the future }\end{array}$ & 3.90 & 4.09 & 3.92 & 3.16 & 3.85 & 3.630 & 196 & 0.007 \\
\hline $\begin{array}{l}\text { am willing to be involved in the } \\
\text { development of CPNP for ecotourism in } \\
\text { the future }\end{array}$ & 4.20 & 4.25 & 4.21 & 3.21 & 3.69 & 5.502 & 196 & 0.000 \\
\hline
\end{tabular}

Superscript numbers indicate that mean values are significantly different from the mean values in the equivalent columns. Numbers denote columns $2-6$, i.e. $1=18-25$ years old, $2=26-35$ years old, $3=36-55$ years old, $4=56-60$ years old, $5=$ Over 60 years old. For example, the first line reads that significant differences existed between those their ages are 26-35 and 56-60; and between those their ages are 36- 55 and 56-60.

(specifically, negative environmental impacts of tourism).

For the job status (Table 6), as found by other studies (Haralambopoulos \& Pizam, 1996; Tatoglu et al., 2000; Andriotis, 2004; Kuvan \& Akan, 2005), findings from this study indicate that those residents with tourism-related jobs tend to approve tourism more than those with non-tourism related jobs. This finding confirms findings by Kayat (2000) that the explanation offered by social exchange theory that benefits received by residents influence their support for tourism needs to be complemented with other explanation as other variables appear to also play a role in resident forming attitudes. As found by the present study, those residents who depend on tourism view tourism favorably compared to those who do not depend on tourism.

For age groups (Table 7), the results of this study are in line with the results of the study by Haralambopoulous and Pizam (1996) as it is found that generally, the younger the residents are, the more positive perceptions they have towards tourism. Gender, place of birth, length of residency also have limited influence on residents' perceptions of tourism impacts, evaluation of tourism impacts, and support for tourism development. Interestingly, marital status has not exhibited any significant effect on residents' perceptions of tourism statements, similar to the result of the study by Kuvan \& Akan (2005). 
Table 8. Multiple Regression of Support for Tourism Development in CPNP

\begin{tabular}{lccc}
\hline Independent Variables & $\boldsymbol{B}$ & $\boldsymbol{t}$ & Sig. \\
\hline Age & -0.141 & -2.571 & 0.011 \\
Gender $^{\mathrm{a}}$ & 0.152 & 2.801 & 0.006 \\
Positive socio-cultural impacts & 0.471 & 7.471 & 0.000 \\
Positive environmental impacts & 0.251 & 3.956 & 0.000 \\
Negative environmental impacts & 0.244 & 4.419 & 0.000 \\
\hline
\end{tabular}

Note. $R^{2}=0.44$, adjusted $R^{2}=0.43, F=30.583, p<0.001$

a. Dummy coded: $0=$ female, $1=$ male.

The above findings do not support hypothesis 1 , which assumes that there are no differences among residents' socio-demographic characteristics with respect to perceptions of tourism impacts, evaluation of tourism impacts and their support for tourism development. As a result, we reject the hypothesis 1 and accept that there are significant differences among residents' socio-demographic characteristics with respect to perceptions of tourism impacts, evaluation of tourism impacts, and their support for tourism development.

\section{Support for tourism development}

To test hypothesis 2, this study used the method of computing multiple regression simultaneously between the dependent variable (support for tourism development) and the independent variables (residents' sociodemographic characteristics, residents' perceptions of tourism impacts, and residents' evaluation of tourism impacts) in order to predict support for tourism development from a combination of a total of 16 independent variables.

Table 8 shows the results of the multiple regression pertaining to support for tourism development in CPNP. As can be seen from this table, $R^{2}=0.44$, and the adjusted $R^{2}$ value for 5 out 16 independent variables considered in the equation is 0.43 , indicating that the model explains $43 \%$ of the variance in support of tourism development.

In particular, the CPNP respondents in support of tourism development were found to have the following perceptions and socio-demographic characteristics:

- The younger the respondent, the more likely he or she was to support tourism development.
- Males were more supportive of tourism development than females.

- Respondents who believed that tourism has positive socio-cultural impacts tended to support tourism development.

- Respondents who believed that tourism has positive environmental impacts tended to support tourism development.

- Finally and interestingly, respondents who believed that tourism has negative environmental impacts also supported tourism development.

It is worth noting that only two out of the nine socio-demographic variables entered the regression equation. Other socio-demographic variables such as ethnicity, place of birth, marital status, level of education, monthly household income, job status, and length of residency did not have a shared effect on the residents' support for tourism development. Interestingly, the other variables that did not have a combined effect on the support levels included the residents' perceptions of positive/negative economic impacts of tourism, their perceptions of negative socio-cultural impacts of tourism, and their evaluation of tourism impact.

These findings are also consistent with the first finding of this study, which signifies that residents in CPNP consider positive sociocultural and environmental impacts of tourism to be more important than positive economic impacts of tourism, implying that they do not support tourism development merely on the grounds of economic aspect. Furthermore, this finding echoes the findings by Andereck and Vogt (2000) and, King, Pizam, and Milman (1993), who concluded that support for tourism development could be associated with the 
belief that tourism induced positive as well as negative impacts. Despite their awareness of tourism's negative impacts, the local residents still support tourism development.

The findings also allow us to reject hypothesis 2 , which assumes that the independent variables (residents' socio-demographic characteristics, perceptions of tourism impacts, and evaluation of tourism impacts) do not significantly explain the dependent variables (residents' support for tourism development).

The findings denote that the theoretical perspective of this research, the social exchange theory, is helpful in guiding research on residents' perceptions of and support for tourism development. Residents in CPNP perceive greater positive impacts of tourism than negative ones, leading to their support for tourism development in CPNP. In addition to the perception of the positive impacts, the study finds that variables such as degree of dependency on tourism may complement the above argument brought about by social exchange theory.

\section{Conclusion}

This study attempts to contribute to the existing body of work on local residents' perception of tourism impacts, their evaluation of tourism impacts, and their support for tourism development. The study develops a research instrument to determine these aspects which may be adopted by other researchers seeking to assess local residents' perceptions of tourism in different geographical areas, especially in Vietnam, where research instruments like this one are still scarce.

The conceptual framework developed and tested in this research offers a theoretical basis for the study of tourism impacts and local support for tourism development. Further testing of residents' perceptions in different areas using this conceptual framework can provide more comprehensive grounds for the comparative study of a variety of residents' perceptions of tourism impacts and support for tourism development. The addition of new variables to the framework may further elucidate these aspects.
This study also further validates to the theoretical predominance in the field of tourism research by confirming the usefulness of the social exchange theory in explaining residents' perceptions of tourism. The findings reveal that when residents perceive that the positive impacts of tourism (regardless of whether they are economic, socio-cultural, or environmental impacts) are likely to be greater than the negative impacts, they are inclined to accept the exchange and, therefore, support tourism development in their community.

One prominent finding of this study is that residents in CPNP valued the socio-cultural and environmental impacts of tourism higher than its economic impacts, and they supported tourism development, in general, but not merely for its economic benefits, unlike the findings of the earlier studies. Consequently, this study obtained its significant results that depending on the residents' socio-demographic characteristics, extent of tourism's influence, and different geographical areas, the local residents' perceptions of and attitudes toward tourism may differ; residents generally tend to support tourism if they feel that tourism brings them more benefits than costs (regardless of whether these are socio-cultural, environmental, or economic benefits). In CPNP, residents value the social-cultural and environmental impacts of tourism more than its economic impacts (because most of them are still dependent on the park's resources and they have not received significant economic benefits from tourism so far); these findings may differ if a similar study is conducted in other destinations.

This research provides tourism planners, policymakers, tourism strategists, and tourism promoters with helpful information about local residents' perceptions, evaluations of tourism impacts, and their support for tourism development; this information can be used to formulate plans and policies not only to gain residents' support for tourism but also to implement sustainable tourism development. The more attentive tourism leaders are to residents' concerns, the greater the support they are likely to receive in their community development efforts (Ramchander, 2004). The 
study findings reveal that at the time of this research, CPNP residents tended to have positive perceptions of tourism and that they largely supported tourism development, especially due to its socio-cultural and environmental impacts. However, to maintain sustainable tourism, it is necessary to take into account a long-term perspective of residents' perceptions of tourism. Furthermore, it is important to involve residents in both tourismrelated decision-making processes and the tourism activity itself, since the findings indicate the local residents' willingness to be involved and participate in these activities. The researcher's observations suggest that thus far the local residents, particularly the Muongs, have very limited involvement in such activities (participating in tourism as the hosts of homestays, selling goods and services, etc.).

This study demonstrates that sociodemographic characteristics of local residents influence their perceptions, evaluation of impacts, and their support for tourism development. In turn, residents' perceptions of tourism impacts brought by ecotourism development in CPNP and their sociodemographic characteristics influence their overall support for tourism development. Future research is needed to investigate why the specific socio-demographic characteristics influence the CPNP residents' perceptions towards tourism in order to make appropriate plans and policies.

In addition, although the local residents' view are critical for analyzing tourism development, in that the greatest impacts of the tourism industry are experienced and judged by the host residents (Andriotis, 2000), further research should investigate the perceptions of tourism organization managers and, local authorities to identify the real concerns and conflicts pertaining to tourism development in CPNP. Such information would lead to a better understanding of the tourism structure in CPNP and help the relevant authorities formulate effective tourism development plans and policies.

This study examines the factors, and variables that explain local residents' perceptions and evaluation of tourism impacts, and their support for tourism development. In order to further understand "why" and "how" the CPNP residents' react to tourism development in a particular manner (that is, why and how residents perceive a specific impact as positive or negative), it is necessary to analyze additional data using qualitative methods in order to collect more insightful and comprehensive information.

The research instrument and conceptual framework developed and tested in this research can be expanded and tested in other geographical locations using larger samples to identify and examine other variables and factors that may influence the residents' abovementioned opinions. Such information will be useful in providing more comparative results and findings in this topic.

Based on previous studies, which had indicated that socio-demographic characteristics might or might not influence residents' perceptions, evaluation of tourism impacts, and their support for tourism development, the findings of this study show that socio-demographic characteristics, especially income, ethnicity, education level, job status, significant influence residents' perceptions. The results of this study also offer some variables, which explain for residents' support for tourism development in CPNP.

In conclusion, let us reflect on the view of McGehee and Andereck (2004: 139) that "a great deal of progress has been made in the study of residents' attitudes towards tourism, but a great deal is left to be done. No matter what future direction resident attitude research takes, the most important goal must be to assure that the varied voices of the community are heard".

\section{References}

Allen, L. R., Hafer, H. R., Long, P. T. \& Purdue, R. R. (1993). Rural Residents' Attitudes toward Recreation and Tourism Development. Journal of Travel Research 31(4), 27-33.

Andereck, K. L., Valentine, K. M., Knopf, R. C. \& Vogt, C. A. (2005). Residents' perceptions of Community Tourism 
Impacts. Annals of Tourism Research 32(4), 1056-1076.

Andereck, K. L. \& Vogt, C. A. (2000). The Relationship between Residents Attitudes towards Tourism and Tourism Development Options. Journal of Travel Research 39(3), 27-36.

Andriotis, K. (2005). Community Groups' Perceptions of and Preferences for Tourism Development: Evidence from Crete. Journal of Hospitality and Tourism Research 29(1), 67-90.

Andriotis, K. (2004). The Perceived Impact of Tourism Development by Cretan Residents. Tourism and Hospitality Planning and Development 1(2), 123144.

Andriotis, K. (2000). Local Community Perceptions of Tourism as a Development Tool: The Island of Crete. $\mathrm{PhD}$ thesis. Bournemouth: Bournemouth University.

Andriotis, K. \& Vaughan D. R. (2003). Urban Residents' Attitudes towards Tourism Development: The Case of Crete. Journal of Travel Research 42(2), 172 185.

Ap, J. (1990). Residents' Perception Research on the Social Impacts of Tourism. Annals of Tourism Research 17(4), 610-615.

Ap, J. (1992). Residents' Perception on Tourism Impacts. Annals of Tourism Research 19(4), 665-690.

Ap, J. \& Crompton, J. L. (1998). Developing and Testing a Tourism Impact Scale. Journal of Travel Research 37(2), 120-131.

Archer, B. \& Cooper, C. (1994). The Positive and Negative Impacts of Tourism. In: W.F. Theobald (Ed.), Global Tourism: The Next Decade. Oxford: Butterworth Heinemann, pp. 63-81.

Beeton, S. (2006). Community Development through Tourism. Landlink.

Brayley, R. \& Var, T. (1989). Canadian Perception of Tourism's Influences on Economic and Social Conditions. Annals of Tourism Research 16(4), 578-582.

Butler, R. W. (1980). The Concept of a Tourist Area Cycle of Evolution: Implications for Management of Resources. In: S. Williams (Ed.), Tourism: Critical Concepts in the Social Sciences, Volume 3: Tourism, Development and Sustainability. London: Routledge, pp. 143-152.
Cavus, S. \& Tanrisevdi, A. (2003). Residents' Attitudes toward Tourism Development: A Case Study in Kusadasi, Turkey. Tourism Analysis 7 (3\&4), 259-269.

Cordero, J. C. M. (2008). Residents' Perception of Tourism: A Critical Theoretical and Methodological Review. Ciencia Ergo Sum 15(1), 35-44.

Chen, J. S. (2000). An Investigation of Urban Tourism Residents Loyalty of Tourism. Journal of Hospitality and Tourism Research 24(1), 5-19.

Chen, J. S. (2001). Assessing and Visualizing Tourism Impacts from Urban Residents Perspective. Journal of Hospitality and Tourism Research 25(3), 235-250.

CPNP (Cuc Phuong National Park) (2004). Constructional Investment Project of CPNP 2005-2008.

Dyer, P., Gursoy, D., Sharma, B. \& Carter, J. (2007). Structural Modelling of Resident Perception of Tourism and Associated Development on the Sunshine Coast, Australia. Tourism Management 28(2), 409-422.

Easterling, D. (2004). The Residents' Perspective in Tourism Research: A Review and Synthesis. Journal of Travel and Tourism Marketing 17(4), 45-62.

Fredline, E. \& Faulkner, B. (2000). Host Community Reactions: A Cluster Analysis. Annals of Tourism Research 27(3), 764-785

Getz, D. (2000). Residents Attitudes towards Tourism: A Longitudinal Study in Spey Valley, Scotland. In C. Ryan \& S. Page (eds.). Tourism Management: Towards the New Millennium. Amsterdam: Pergamon, pp.139-154.

Gursoy, D., Jurowski, C. \& Uysal, M. (2002). Resident Attitudes: A Structural Modeling Approach. Annals of Tourism Research 29(1), 79-105.

Haralambopoulos, N. \& Pizam, A. (1996). Perceived Impact of Tourism: the Case of Samos. Annals of Tourism Research 23(3), 503-526.

Harrill, R (2004). Residents' Attitudes toward Tourism Development: A Literature Review with Implications for Tourism Planning. Journal of Planning Literature 18(3), 251-266.

Harvey, M. J., Hunt, J. \& Harris, C. C. J. (1995). Gender and Community Tourism 
Development. Annals of Tourism Research 22(2), 349-366.

Hernandez, S. A., Cohen, J. \& Garcia, H. L. (1996). Residents' Attitudes Towards and Instant Resort Enclave. Annals of Tourism Research 23(4), 755-779.

Inskeep, E. (1991). Tourism Planning: An Integrated and Sustainable Development Approach. New York: Van Nostrand Reinhold.

Jackson, M. \& Inbakaran, R. (2004). Community Residents' Attitudes towards Tourism Development: Do Attitudes Predict Intention to Act? In K. A. Smith \& C. Schott (Eds), Proceedings of the New Zealand Tourism and Hospitality Research Conference 2004. Wellington, 8-10 December, pp. 159-169.

Jennings, G. (2001). Tourism Research. Brisbane: John Wiley \& Sons.

Johnson, J. D., Snepenger, D. J \& Akis, S. (1994). Residents' Perceptions of Tourism Development. Annals of Tourism Research 21(3), 629-642.

Jurowski, C., Uysal, M. \& William, D. R. (1997). A Theoretical Analysis of Host Community Residents Reactions to Tourism. Journal of Travel Research 36(2), 3-11.

Kayat, K. (2002). Power, Social Exchanges and Tourism in Langkawi: Rethinking Resident Perceptions. International Journal of Tourism Research 4(3), 171191.

Kayat, K. (2000). Power through Tourism: A Blessing on Mahsuri's Eighth Generation in Langkawi? PhD thesis. Michigan: Michigan State University.

Kayat, K. \& Propst, D. (2001). Exchanges between Residents and Tourism Development. Malaysian Management Journal 5(1\&2), 1-15.

King, B., Pizam, A. \& Milman, A. (1993). Social Impacts of Tourism: Host Perceptions. Annals of Tourism Research 20(4), 650665.

Kinnear, P. R. \& Gray, D. C. (2004). SPSS 12: Made Simple. Hove and New York: Psychology Press.

Ko, D. W. \& Stewart, W. P. (2002). A Structural Equation Model of Residents' Attitudes for Tourism Development. Tourism Management 23(5), 521-530.

Kreag, G. (2001). The Impact of Tourism. Minnesota Sea Grant: University of Minnesota.
Kuvan, Y. \& Akan, P. (2005). Residents' Attitudes toward General and Forest-related Impact of Tourism: the Case of Belek, Antalya. Tourism Management 26(5), 691-706

Lankford, S. V., (1994). Attitudes and Perceptions toward Tourism and Rural Regional Development. Journal of Travel Research 32(3), 35-33.

Lankford, S. V \& Howard, D. (1994). Developing a Tourism impact Attitude Scale. Annals of Tourism Research 21(1), 121-139.

Lickorish, J. \& Jenkins, C. L. (1997). An Introduction to Tourism. Oxford: Butteworth-Heinemann.

Lindberg, K. \& Johnson, R. (1997). Modeling Resident Attitudes toward Tourism. Annals of Tourism Research 24(2), 402424.

Madrigal, R. (1993). A Tale of Tourism in Two Cities. Annals of Tourism Research 20(1), 336-353.

Mathieson, A. \& Wall, G. (1982) Tourism: Economic, Physical, and Social Impacts. New York: Longman House.

McCool, S. F. \& Martin, S. R. (1994). Community Attachment and Attitudes toward Tourism Development. Journal of Travel Research 32(3), 29-34.

McGehee, N. G. \& Andereck, K. L. (2004). Factors Predicting Rural Residents' Support of Tourism. Journal of Travel Research 43(2), 131-140.

McGehee, N. G., Andereck, K. L. \& Vogt, C. A. (2002). An Examination of Factors Influencing Resident Attitudes toward Tourism in Twelve Arizona Communities. URL:

http://www.ttra.com/pub/uploads/023.pdf (Accessed on 12/12/2008)

Milman, A. \& Pizam, A. (1988). Social Impacts of Tourism on Central Florida. Annals of Tourism Research 15(2), 191-204.

Nepal, S. (2008) Residents' Attitudes to Tourism in Central British Columbia, Canada. Tourism Geographies 10(1), 42-65.

Nunkoo, R., Gursoy, D. \& Juwaheer, T. D. (2010). Island Residents' Identities and Their Support for Tourism: An Integration of Two Theories. Journal of Sustainable Tourism 18(5), 675-693.

Nunkoo, R. \& Ramkissoon, H. (2010). Small Island Urban Tourism: A Residents' Perception. Current Issue in Tourism 13(1), 37-60. 
Perdue, R. R., Long, P. T. \& Allen, L. (1990). Residents Support for Tourism Development. Annals of Tourism Research 17(4), 586-599.

Phuc, H. D. (2005). Using SPSS in Data Analysis. Hanoi: Technology and Science Publishing House.

Ramchander, P. (2004). Towards the Responsible Management of the SocioCultural Impacts of Township Tourism. $\mathrm{PhD}$ thesis. Pretoria: University of Pretoria.

Rátz, T. (2000). Residents' Perceptions of The Social-Cultural Impacts of Tourism at Lake Balaton, Hungary. In G., Richards \& D. Hall (Eds), Tourism and Sustainable Community Development. London: Routledge, pp. 36-47.

Ritchie, B. W. \& Inkari, M. (2006). Host Community Attitudes toward Tourism and Cultural Tourism Development: the Case of the Lewes District, Southern England. International Journal of Tourism Research 8(1), 27-44.

Ryan, C. \& Montgomery, D. (1994). The Attitudes of Bakewell Residents to Tourism and Issues in Community Responsive Tourism. Tourism Management 15(5), 358-369.

Ryan, C., Scotland, A. \& Montgomery, D. (1998). Resident Attitudes to Tourism Development - A Comparative Study between the Rangitikei, New Zealand and Bakewell, United Kingdom. Progress in Tourism and Hospitality Research 4(2), 115-130.

Sheed, C. (2003). Between a Rock and Hard Place: Ecotourism in Babe National Park, Vietnam. An Honours Research Project. Bahurst, New South Wales: Charles Sturt University.

Sheldon, P. J. \& Var, T. (1984). Resident Attitudes to Tourism in North Wales. Tourism Management 5(1), 40-47.
Sirakaya, E., Teye, V. \& Sönmez, S. (2002). Understanding Residents' Support for Tourism Development in the Central Region of Ghana. Journal of Travel Research 41(1), 57-67.

Sirakaya, E., Teye, V. \& Sönmez, S. (2001). Examining the Sources of Differential Support for Tourism Industry in Two Ghanaian Cities. Tourism Analysis 6(1), 29-40.

Smith, M. D. \& Krannich, R. S. (1998). Tourism Dependence and Resident Attitude. Annals of Tourism Research 25(4), 783802.

Tatoglu, E., Erdal, F., Ozgur, H. \& Azakli, S. (2000). Resident Perceptions of the Impact of Tourism in a Turkish Resort Town.

URL: http://www.opf.slu.cz/vvr/akce/turecko/pd $\mathrm{f} /$ Tatoglu.pdf (Accessed on 12/12/2008).

Teye, V., Sönmez, S. \& Sirikaya, E. (2002). Residents' Attitudes toward Tourism Development. Annals of Tourism Research 29(3), 668-688.

Thomason, P., Crompton, J. \& Kamp, B. (1979). A Study of the Attitudes of Impacted Groups within a Host Community Toward Prolonged Stay of Tourist Visitors. Journal of Travel Research 17(3), 2-6.

Tosun, C. (2002). Host Perception of Impacts: A Comparative Tourism Study. Annals of Tourism Research 29(1), 231-253.

Wang, Y. \& Pfister, R. E. (2008). Residents' Attitudes toward Tourism and Perceived Personal Benefits in a Rural Community. Journal of Travel Research 47(1), 84-93.

Williams, J. \& Lawson, R. (2001). Community Issues and Resident Opinions of Tourism. Annals of Tourism Research 28(2), 269-290.

Yoon, Y., Gursoy, D. \& Chen, J. S. (2001) Validating a Tourism Development Theory with Structure Equation Modeling. Tourism Management 22(4), 363-372. 